\title{
ZAKONSKI OKVIRI I PLANIRANJE GOSPODARENJA CESTAMA
}

\author{
Martina Marević \\ Sveučilište Josipa Jurja Strossmayera u Osijeku, Građevinski fakultet Osijek, studentica \\ Irena lštoka Otković \\ Sveučilište Josipa Jurja Strossmayera u Osijeku, Građevinski fakultet Osijek, dr.sc.
}

Sažetak: Završetkom razdoblja intenzivne gradnje prometnica, dominantnim postaje gospodarenje prometnom infrastrukturom. Održavanje prometnica obavlja se sukladno propisima koje donosi Vlada Republike Hrvatske. U okviru rada analiziraju se zakonski i podzakonski akti koji utječu na planiranje održavanja prometnica i analizira se održavanje prometnica u praksi na primjeru Osijeka. Uspostava sustava gospodarenja cestama, iako iziskuje dodatne napore i sredstva, nema alternativu u postupku gospodarenja cestama i donijet će višestruke koristi donosiocima odluke, korisnicima i sustavu u cjelini, kao što pokazuju iskustva drugih zemalja u Europi i svijetu.

Ključne riječi: gospodarenje cestama; zakoni; pravni subjekti; strategije održavanja

\section{LEGAL FRAMEWORKS AND PLANNING OF ROAD MANAGEMENT}

\begin{abstract}
After intensive road construction, road management becomes of crucial importance. Maintenance of roads is carried out in accordance with laws passed by the Croatian government. Within the framework of this paper the legal acts affecting planning of road maintenance are analyzed, and one example of practical road maintenance in the town of Osijek is presented. A system of road management, although it requires additional efforts and means, will bring multiple benefits to decision makers, users and the system in general, as evident from experience of other countries in Europe and worldwide.
\end{abstract}

Key words: road management; laws; legal entities; maintenance strategies 


\section{Uvod}

Intezivna izgradnja prometne infrastrukture stagnira, a dominantnim zadatkom postaje gospodarenje izgrađenim prometnicama radi postizanja i održavanja određene, zakonom minimalno propisane, razine uporabljivosti cestovnog prometnog sustava. Planiranje gospodarenja cestama uključuje ocjenu stanja, odlučivanje 0 prioritetima održavanja i niz aktivnosti koje su usmjerene na podizanje uporabne razine cestovnih prometnica. Propisi koje donosi Vlada Republike Hrvatske stvaraju jasan okvir aktivnostima koje je potrebno provesti u postupku gospodarenja cestama. Zakonski i podzakonski akti propisuju način provođenja tih aktivnosti i pravne subjekte koji su odgovorni za njihovo provođenje. Strategije gospodarenja cestama su postupci donošenja dokumentirane i stručne odluke - gdje, kada i kako implementirati određene mjere, za koja sredstva, i koji su očekivani rezultati tih aktivnosti. Praksa u svijetu je uspostavljanje sustava gospodarenja cestama i donošenje odluka uz pomoć računalnih modela odlučivanja koji obuhvaćaju baze podataka o cestama i pokazateljima stanja cesta i objekata. U okviru ovog rada uspoređene su i prodiskutirane različite strategije održavanja cestovne infrastrukture. Analizirane su aktivnosti održavanja koje pravni subjekti koji djeluju u lokalnoj sredini provode u praksi, u kontekstu zakonom propisanih obveza održavanja i u kontekstu stručnih preporuka i iskustava drugih zemalja.

\section{Zakonski okviri gospodarenja cestama}

Zakonodavstvo svake zemlje uređuje pitanja gospodarenja cestama i održavanja cestovne mreže i pratećih objekata kao pitanja upravljanja javnim dobrom u općoj uporabi. Cilj zakonskih okvira [1-10] je sustavno podizanje uporabne razine cesta i održavanja što je moguće kvalitetnijeg stanja cestovne mreže uz optimiziranje potrošnje raspoloživih resursa. Prema Pravilniku o zaštiti i održavanju javnih cesta (NN 25/98 i 162/98), može se reći da je održavanje skup operacija koje je potrebno povremeno obavljati na cestama i objektima zbog slobodnog odvijanja prometa pod normalnim uvjetima sigurnosti i udobnosti vožnje bez obzira na godišnje doba i sprječavanja progresivnog propadanja cesta pod djelovanjem prometnog opterećenja i klimatskih prilika.

Održavanje cesta se radi zbog [4] sprječavanja propadanja cesta, omogućavanja sigurnog odvijanja prometa, smanjenja troškova korisnika dobrim stanjem cesta, dovođenja ceste u projektirano stanje uzimajući u obzir izmijenjene potrebe prometa, zaštite ceste od korisnika i trećih osoba, zaštite okoliša od štetnog utjecaja ceste i cestovnog prometa. Temeljni preduvjeti održavanja i zaštite cesta su [4] referentni sustav označavanja cesta, baza cestovnih podataka, praćenje stanja cesta i objekata i modeli odlučivanja.

Odlukom o razvrstavanju javnih cesta [8] propisano je koji pravni subjekti gospodare određenom razinom cesta (slika 1) u prometnoj mreži. Sve aktivnosti koje propisuju zakoni su obvezne i obvezujuće za pravne subjekte koji gospodare cestama. Pravni subjekti koji gospodare cestama imaju ovlast prenijeti radove održavanja na druge subjekte, ali oni i dalje ostaju odgovorni za provođenje i kvalitetu radova održavanja koje su zakonom propisane.

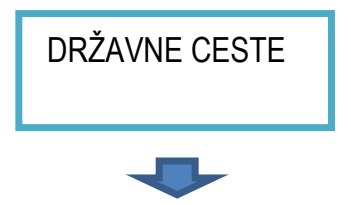

HRVATSKE CESTE d.o.0.

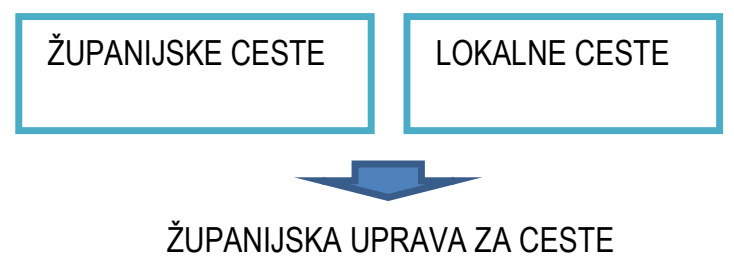

ŽUPANIJSKA UPRAVA ZA CESTE

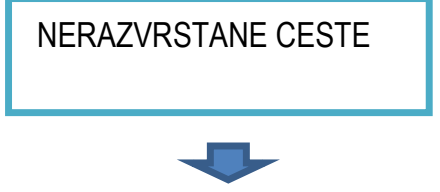

GRAD/LOKALNA SAMOUPRAVA

\section{Slika 1 - Administrativna podjela cesta i subjekata koji gospodare cestama}

Za provedbu godišnjeg plana održavanja cesta izrađuje se operativni program radova održavanja cesta. Operativni program izrađuje se posebno za održavanje cesta u zimskom razdoblju. Operativnim programom 
radova određuju se potrebna financijska sredstva, materijali, količina i vrsta radova i rokovi izvršenja za svaku cestu ili dionicu ceste.
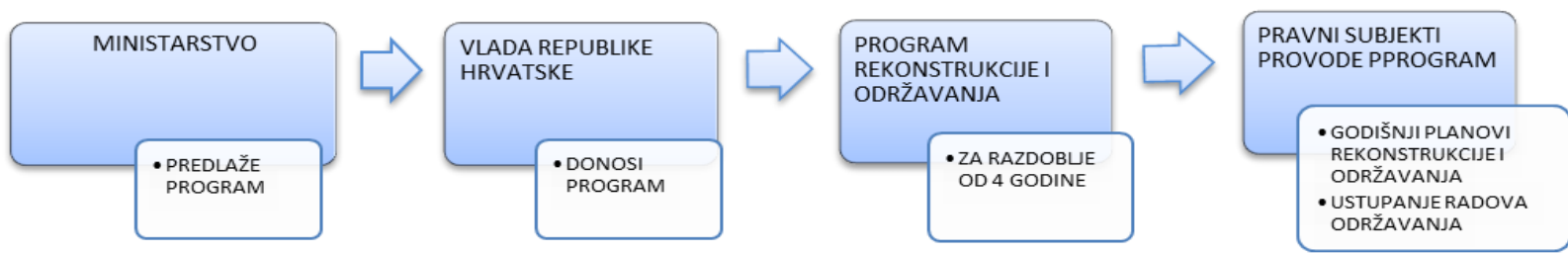

\section{Slika 2 - Program rekonstrukcije i održavanja državnih cesta}

Donošenje programa rekonstrukcije i održavanja državnih cesta (slika 2) analogno vrijedi i za županijske i za nerazvrstane ceste. Godišnje planove rekonstrukcije i održavanja cesta za županijske ceste donosi županijska skupština, iste planove za nerazvrstane ceste donosi gradsko poglavarstvo.

\subsection{Zakonom predviđene razine održavanja cesta}

Pravilnikom [4] su određene osnovne razine održavanja cesta (slika 3):

- redovito održavanje obuhvaća radove na cestama koji se obavljaju neprekidno tijekom cijele godine (planirano, interventno) i godišnji plan zimske službe

- izvanredno održavanje čine radovi većeg opsega koji se dugoročno planiraju ili koji nastaju kao posljedica nepredviđenih događaja

- rekonstrukcija je izvođenje građevinskih radova na postojećoj građevini ili poduzimanje mjera radi uspostave primjerenog stanja postojeće građevine ako se tim radovima i mjerama utječe na bitne tehničke elemente građevine.

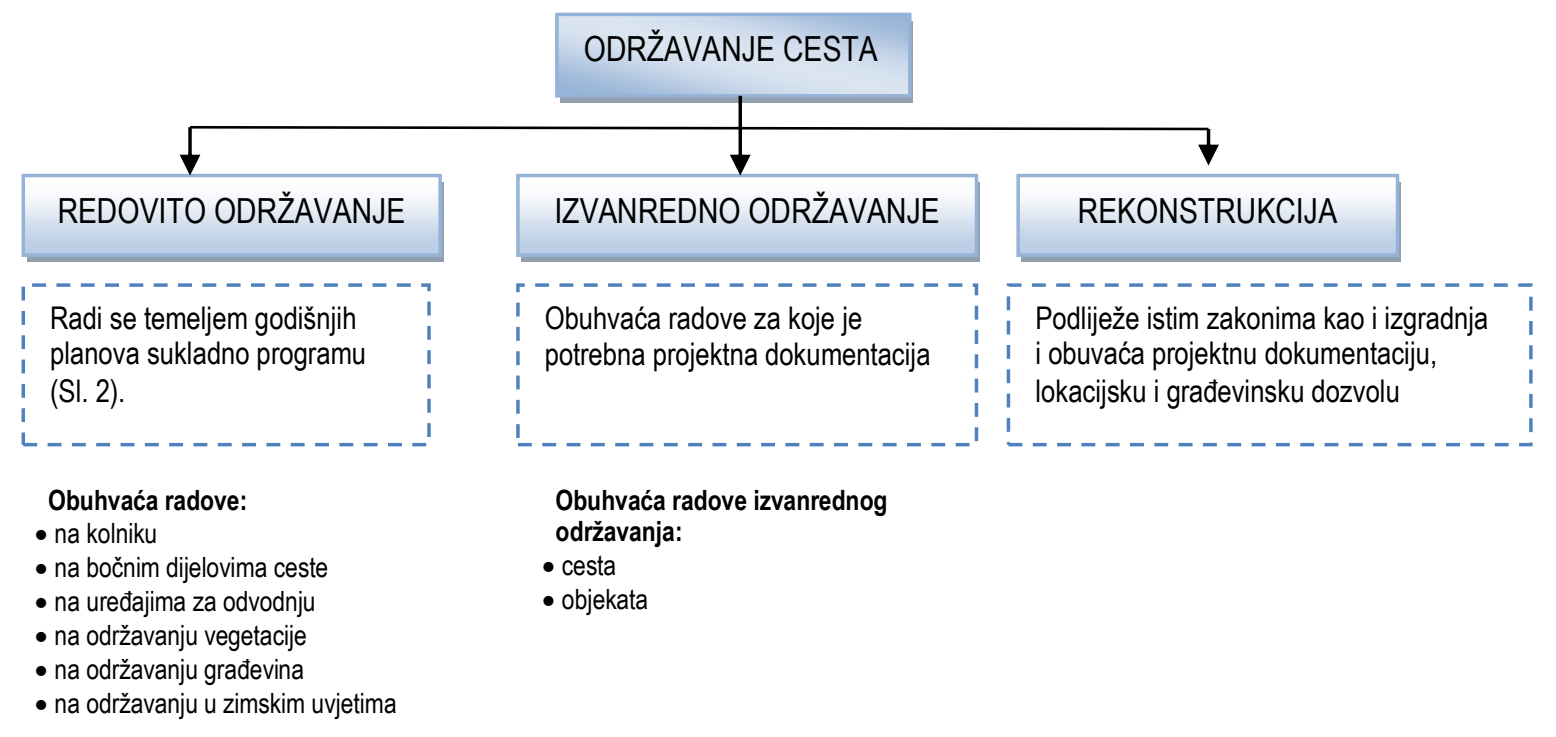

\section{Slika 3 -Osnovne razine održavanja cesta}

Zakoni propisuju razine održavanja, aktivnosti održavanja, kriterije odlučivanja i prioritete održavanja. Zakonski okvir čine zakonski i podzakonski akti:

[1] Zakon o sigurnosti prometa na cestama (NN 67/08, 74/11)

[2] Zakon o prostornom uređenju i gradnji ( NN 76/07, 38/09, 55/11, 90/11)

[3] Zakon o cestama (NN 84/11) 
[4] Pravilnik o zaštiti i održavanju javnih cesta (NN 25/98 i 162/98)

[5] Pravilnik o osnovnim uvjetima kojima javne ceste izvan naselja i njihovi elementi moraju udovoljavati s gledišta sigurnosti prometa (NN 110/01)

[6] Pravilnik o minimalnim sigurnosnim zahtjevima za tunele NN119/09)

[7] Pravilnik o uvjetima i postupku zatvaranja javnih cesta (NN119/07)

[8] Odluka o razvrstavanju javnih cesta u državne ceste, županijske ceste i lokalne ceste (NN 54/08, $122 / 00,13 / 09,104 / 09$ i $17 / 10,44 / 12$ )

[9] Odluka o razvrstavanju javnih cesta u autoceste (NN77/07, 13/09 i 104/09)

[10] Zakon o komunalnom gospodarstvu (NN 26/03, 82/04,110/04, 178/04, 38/09, 79/09, 153/09, 49/11, 84/11 i 90/11).

Osnovne teme kojima se zakoni i podzakonski akti bave u uređivanju održavanja cestovne infrastrukture su sumarno prikazane u tablici 1.

Tablica 1 - Osnovne teme održavanja cesta kojima se bave zakoni i podzakonski akti

\begin{tabular}{c|l}
\hline \multicolumn{1}{|c}{ Legislativa } & \multicolumn{1}{c}{ OSNOVNE TEME } \\
\hline \hline$[2],[3],[4],[10]$ & Osnovne razine održavanja cesta \\
\hline$[3],[4]$ & Aktivnosti održavanja javnih cesta, objekata i signalizacije \\
\hline$[3],[4]$ & Aktivnosti održavanja raskrižja, prijelaza i križanja \\
\hline$[3],[4]$ & Uvjeti preglednosti \\
\hline$[1],[3],[4],[5],[6],[7]$ & Minimalni uvjeti sigurnosti cesta i cestovnih objekata \\
\hline$[3],[4],[8],[9],[10]$ & Pravni subjekti koji gospodare cestama i nadležnosti \\
\hline$[3],[4]$ & Aktivnosti nadzora i inspekcije \\
\hline$[3],[4]$ & Standardi održavanja \\
\hline$[3],[4]$ & Planovi održavanja cesta \\
\hline$[3],[4]$ & Preduvjeti gospodarenja cestama \\
\hline$[3]$ & Naplata cestarine \\
\hline$[3]$ & Kriteriji za utvrđivanje prioriteta održavanja \\
\hline$[3]$ & Ustupanje radova održavanja \\
\hline$[3],[10]$ & Koncesije \\
\hline$[3]$ & Mjere zaštite javnih cesta \\
\hline$[3],[10]$ & Nerazvrstane ceste \\
\hline
\end{tabular}

\section{Strategije gospodarenja cestama}

Prema OECD1, gospodarenje cestama je sustavno održavanje, poboljšavanje i korištenje cestovne imovine, kombiniranjem inženjerskih principa s dobrom poslovnom praksom i ekonomskom racionalnošću, osiguravajući alate za primjenu organiziranijeg i fleksibilnijeg pristupa za donošenje odluka neophodnih za ispunjavanje očekivanja javnosti. Strategije gospodarenja cestama moraju biti bazirane na načelu dugoročnog planiranja, a odgovarajuća strategija bira se u kontekstu postavljenih ciljeva, vremena i raspoloživih resursa.

1 OECD - Organization for Economic Cooperation and Development (Organizacija za ekonomsku suradnju i razvoj) 
Metode gospodarenja cestama mogu se podijeliti u dvije osnovne grupe, a to su metode na razini mreže i na razini projekta. U novije vrijeme gospodarenje cestama bazirano je na metodama dvorazinske analize koje obuhvaćaju obje razine, ali razlicitih prioriteta. Prva grupa metoda su metode od vrha prema dolje - prvo se razmatraju odluke na razini mreže, a druga grupa metoda je od dna prema vrhu - prvo se razmatraju odluke na razini projekta. Količina i kvaliteta podataka i analitička mogućnost diktiraju hoće li primijenjene metode biti vrlo detaljne ili relativno jednostavne [11] .

Gospodarenje kolnicima je bitan element gospodarenja cestama. Izdvojene su tri osnovne metode gospodarenja kolnicima:

- analiza stanja kolnika (pristup na razini projekta) - smatra se najjednostavnijom metodom, agregira informaciju o stanju kolnika na razini projekta i onda odabire najprikladniju strategiju - OR\&R (održavanje, rehabilitacija ili rekonstrukcija). Svakom projektu se dodjeljuje prioritet utemeljen na brojnim čimbenicima (lokacija, promet, sigurnost, itd.), zatim se OR\&R projekti kolnika odabiru po prioritetu, sukladno proračunu na razini mreže. Nedostatak ovog sustava je što ne razmatra buduće stanje kolnika.

- modeli ocjenjivanja prioriteta (pristup na razini projekta) - metoda poboljšava analizu stanja kolnika, uključujući informaciju o predviđenom budućem stanju kolnika. Ovi modeli razmatraju buduća predviđena stanja i mogu razmatrati ograničene „,̌̌to ako" scenarije temeljene na odlukama na razini mreže. Mogućnost uvjetnog („što ako") scenarija je limitirana, jer se drugačije odluke mogu modelirati samo mijenjanjem podataka na razini projekta, što je vremenski zahtjevna zadaća.

- modeli optimizacije mreže (pristup na razini mreže) - ova metoda se smatra najsofisticiranijom, ona simultano analizira cijelu cestovnu mrežu radi određivanja optimalne strategije gospodarenja kolnicima za cestovnu mrežu. Zatim se odabiru specifični OR\&R projekti i lokacije da se ta strategija realizira.

Pristup od vrha prema dolje na razini mreže omogućava: bolju institucionalnu kontrolu, jasne prednosti u razmatranju različitih scenarija, sposobnost najboljeg prilagođavanja promjenjivim političkim i društvenim okolnostima. Pristup od dolje prema gore na razini projekta pruža samo osnovne mogućnosti razmatranja scenarija, ali može osigurati mnogo detaljnije i točnije podatke koji podržavaju odluke vezane uz pojedinačne projekte [11].

Strategija gospodarenja na razini mreže podrazumijeva: ocjenu stanja cesta i objekata na početku planskog razdoblja, donošenje planova održavanja (prema prioritetima stručne ocjene) i utroška sredstava, provođenje planiranih mjera i monitoring, odnosno ocjena uspješnosti apliciranih mjera u odnosu na očekivane rezultate. Kako se i na koji način provodi svaka od pojedinih aktivnosti održavanja, propisano je zakonskim i podzakonskim aktima.

Strategije gospodarenja usmjerene su na preventivno održavanje cesta. Preventivno održavanje je organizirani sustavni proces primjene niza postupaka preventivnog održavanja tijekom životnog vijeka ceste radi minimiziranja troškova tijekom životnog vijeka (OECD), jednostavnije rečeno to je primjena pravog postupka na pravu cestu u pravo vrijeme (AASHTO²). Korištenjem preventivnog održavanja cesta smanjuje se obim skupih i vremenski zahtjevnih radova održavanja u projektnom periodu i/lii se odgađa vrijeme kada je takve radove potrebno aplicirati. Koristi od preventivnog održavanja su veće zadovoljstvo korisnika, bolje stanje kolnika, uštede u troškovima, povećana sigurnost, odluke na osnovi boljih informacija. Reaktivno (korektivno) održavanje je interventno održavanje u kojemu nisu unaprijed definirani ni prostorni, ni vremenski, ni financijski okviri u kojima je potrebno obaviti određeni zahvat.

$\mathrm{Na}$ slici 4 prikazana je usporedba utjecaja preventivnog i reaktivnog održavanja na stanje kolnika. Preventivnim održavanjem moguće je duže vrijeme održati visoku uporabnu razinu kolnika i odgoditi potrebu za rehabilitacijom ili potpunom sanacijom kolnika, kao što je vidljivo na slici. Na primjeru kada kolnik u prvoj fazi eksploatacije, kada je bio u dobrom stanju, nije održavan, vidi se da propada brže od održavanog. Uložena sredstva u reaktivno održavanje, kada je stanje kolnika bilo značajno lošije, nisu na duži rok odgodila vrijeme kada je potrebna potpuna sanacija. Neodržavanje i zakašnjelo interventno održavanje skraćuje ukupni životni vijek kolnika i može dovesti do takvog stanja da cesta postane neupotrebljiva dok se ne izvrši potpuna sanacija, što uzrokuje niz neželjenih posljedica - ekonomskih, sigurnosnih i ekoloških gubitaka za korisnike i cijeli prometni sustav.

${ }^{2}$ AASHTO-American Association of State Highway and Transportation Officials (Američka udruga za javne ceste i transport) 


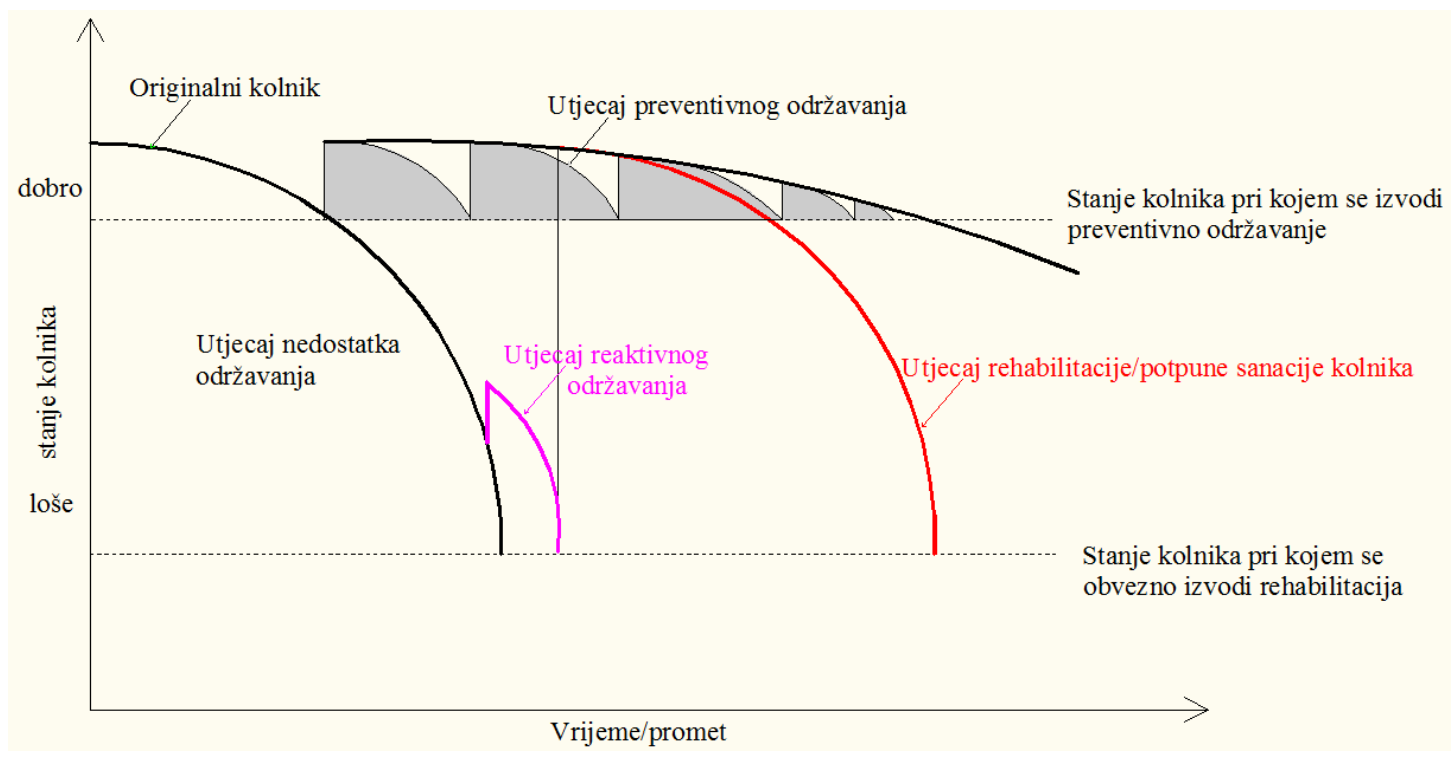

Slika 4 - Posljedice različitih pristupa održavanja na stanje ceste $[12,13]$

Iskustva gospodarenja cestama pokazuju da se plansko i preventivno održavanje pokazalo najučinkovitijim i najisplativijim i prema kriterijima stanja kolnika (slika 4) i objekata i prema kriterijima potrošnje sredstava. U praksi nije u potpunosti moguće izbjeći reaktivno (interventno) održavanje, ali je intencija da u gospodarenju cestama prevladava preventivno održavanje.

\subsection{Ocjena stanja}

Održavanje cestovne infrastrukture obuhvaća održavanje kolnika,održavanje objekata,održavanje prometne signalizacije i održavanje sustava za odvodnju. Da bi se cesta mogla kvalitetno održavati i obnavljati potrebno je utvrditi postojeće stanje i poznavati mehanizme nastanka i uzroka oštećenja kolnika, objekata, signalizacije ili sustava za odvodnju.

U nastavku je detaljno opisana ocjena stanja kolnika, ali na isti način se analiziraju i ostali elementi ceste. Za svaku dionicu treba odrediti stanje kolnika i prometno opterećenje i treba ga povezati s vrstom zahvata kojim će se kvalitetno riješiti problem.

Podatci koji se prikupljaju za kolnik su [12]: uzdužna ravnost, poprečna ravnost (kolotrazi), oštećenje površine ceste (udarne jame, pukotine), nosivost (strukturna čvrstoća) i otpor trenju. Nosivost kolničke konstrukcije (strukturna čvrstoća) ima najveću važnost za inženjere koji održavaju ceste, ali ne predstavlja karakteristiku kolnika koju direktno percipiraju korisnici. Raspucalost površine ceste, brze promjene neravnosti često su pokazatelji nedovoljne nosivosti kolnika [11], što se direktno nepovoljno odražava na korisnike. Nedovoljna nosivost kolničke konstrukcije dovodi do niza neželjenih posljedica - ograničenje prometa, što znači gubitke za korisnike i sustav u cjelini i brzog propadanje kolnika. Otpor trenju (hvatjjivost) jedno je od ključnih svojstava površine ceste koje direktno utječe na sigurnost vožnje. U umjerenim klimama s visokim razinama kišnih oborina, hvatljivost može biti jedan od najvažnijih parametara stanja ceste pa to svojstvo treba uključiti u sustav odlučivanja [11].

Podatci i tehnički parametri koji su prikupljeni pregledom kolnika ulaze u procedure gospodarenja na način da se tehnički parametri (TP) preko transformacijskih funkcija pretvaraju u bezdimenzionalne pojedinačne pokazatelje stanja (Perfomance Indicators, PI), prikazane u tablici 2. Skupovi pojedinačnih pokazatelja stanja (PI) korigiraju se faktorima težine utjecaja (W) i tvore kombinirane bezdimenzionalne pokazatelje stanja (CPI) obzirom na sigurnost, udobnost, nosivost i utjecaj na okolinu. Korigirani kombinirani bezdimenzionalni pokazatelji stanja objedinjuju se u opće bezdimenzionalne pokazatelje stanja (GPI) za svaku dionicu. Pokazatelji stanja određuju homogene dionice kojima je, provjerama graničnih vrijednosti, moguće pridružiti tipizirane vrste popravaka, primjenjivih za određeno stanje homogene dionice. Nakon što se zadaju uvjeti koje treba zadovoljiti, izrađuju se 
različiti scenariji/strategije održavanja za plansko razdoblje. Izabire se ona strategija koja pokazuje najpovoljniji odnos utrošenih proračunskih sredstava i pokazatelja stanja i to je strategija održavanja za iduće plansko razdoblje.

\section{Tablica 2 - Pojedinačni pokazatelji stanja (PI) [12]}

\begin{tabular}{c|c|c|c}
\hline PI & Opis & Tehnički parametar & Jedinična mjera \\
\hline \hline PI_E & Uzdužna ravnost & IRI & $\mathrm{mm} / \mathrm{m}$ \\
PI_R & Poprečna ravnost & RD & $\mathrm{mm}$ \\
PI_T & Dubina teksture & MPD & $\mathrm{mm}$ \\
PI_F & Hvatljivost & SFC,LFC & - \\
PI_B & Nosivost & DEF & $\mu \mathrm{m}$ \\
PI_CR & Pukotine & CR & $\%$ \\
PI_SD & Oštećenja površine & SD & $\%$ \\
\hline
\end{tabular}

Osnova za izradu strategije gospodarenja je model ponašanja kolnika u određenim uvjetima u funkciji vremena [12]. Izračunati pokazatelj stanja kolnika smješta promatrani kolnik u točku krivulje dotrajavanje/vrijeme, a time i u područje mogućih tipiziranih radova popravaka (slika 5).



\section{Slika 5 - Tipična linija dotrajavanja asfaltnog kolnika [12]}

Postupak izrade strategije gospodarenja cestama obuhvaća računanje pokazatelja stanja homogenih dionica prema modelu ponašanja kolnika za svaku godinu planskog razdoblja, provjeru svih uvjeta koji su dani u postavkama scenarija i, ovisno o rezultatima provjera, odlučuju koje dionice i s kakvim zahvatom ulaze u plan održavanja u promatranoj godini. Izlazni rezultati postupka su godišnji, četverogodišnji i višegodišnji planovi održavanja - popis dionica s vrstom predviđenih zahvata i njihovim troškovima, ukupni neposredni troškovi, ukupni posredni troškovi, gubitak temeljne vrijednosti cestovne mreže i veličine pokazatelja stanja kolnika [12].

\subsection{Modeli odlučivanja}

Osnovna zadaća modela odlučivanja je pomoći u postupku izrade alternativnih strategija gospodarenja, u analizi i donošenju odluka o najpovoljnijoj - optimalnoj strategiji gospodarenja i prioritetima u održavanju cesta. Zakon predviđa uvođenje modela odlučivanja za pravne subjekte koji gospodare cestama u Hrvatskoj, kako bi se olakšalo gospodarenje cestovnom imovinom.

Računalni modeli odlučivanja obuhvaćaju informacijski sustav podataka o cestama, analizu različitih kriterija odlučivanja, analizu i donošenje prioriteta u izvođenju radova održavanja prema postavljenim kriterijima odlučivanja. Uspostava modela odlučivanja uključuje tri dijela koji se međusobno isprepliću, a to su: izgradnja i 
održavanje računalnog sustava, izgradnja i održavanje baze podataka i izgradnja i održavanje modela za analizu troškova tijekom životnog ciklusa imovine.

U svijetu je razvijen veliki broj računalnih modela koji pomažu korisnicima u složenom postupku izbora optimalne strategije gospodarenja cestama i cestovnom imovinom. Brojni modeli se razlikuju i uglavnom su prilagođeni potrebama i specifičnostima zemalja za koje su razvijeni. Primjeri računalnih modela koji se koriste u svijetu su HDM-4 model, računalni program dTIMS CT i drugi. U Hrvatskoj je takav sustav uspostavljen za potrebe gospodarenja građevinama kojima upravljaju Hrvatske autoceste d.o.o. Napravljeni su modeli sustava gospodarenja za mostove i odvodnju, a predviđa se proširenje sustava modelima za gospodarenje kolnicima, tunelima, geotehničkim građevinama, te modelima za građevine visokogradnje i opremu autoceste.

\section{Analiza stanja u praksi}

U sklopu ovoga rada napravljena je analiza postupaka održavanja koju u praksi provode pravni subjekti koji djeluju na području grada Osijeka. Na promatranom području izgrađeno je ukupno 388,495 km cestovne mreže koju čine državne ceste, županijske ceste, lokalne ceste i nerazvrstane ceste. Sukladno tome postoje tri pravna subjekta koji skrbe o cestovnoj mreži, a to su Hrvatske ceste - Ispostava Osijek, Županijska uprava za ceste i Grad Osijek.

Hrvatske ceste - Ispostava Osijek skrbi o državnim cestama na području Osječko-baranjske (slika 6) i Vukavarsko-srijemske županije. Na području Osječko-baranjske županije ima ukupno 15 cesta ukupne duljine $498,062 \mathrm{~km}$ koje su podijeljene na 32 dionice, a od toga na samom području grada Osijeka postoji pet državnih cesta čija ukupna duljina iznosi 53,500 km koje su u nadležnosti Hrvatskih cesta - Ispostave Osijek. Na području Vukovarsko-srijemske županije, Hrvatske ceste - Ispostava Osijek skrbi o ukupno 258,745 km državnih cesta koje su podijeljene na 8 cesta i 16 dionica.

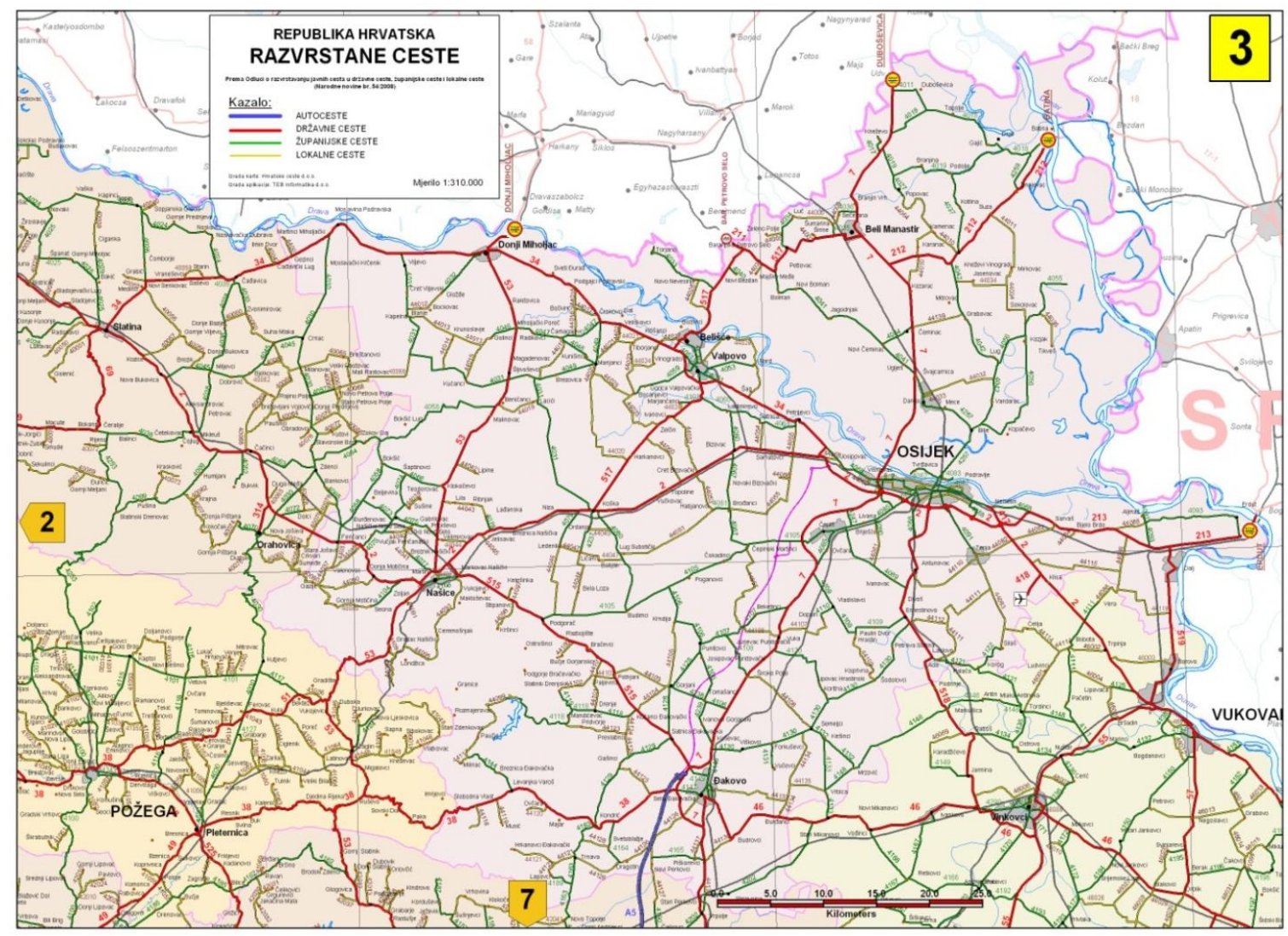

Marević, M; Ištoka Otković, I 


\section{Slika 6 - Razvrstane ceste na području Osječko-baranjske županije ${ }^{3}$}

Županijska uprava za ceste Osječko-baranjske županije skrbi o županijskim i lokalnim cestama na području cijele Osječko-baranjske županije (slika 6). Na području grada Osijeka ima ukupno 25 županijskih cesta kojih ukupne duljine iznose $54,495 \mathrm{~km}$ i 31 lokalna cesta ukupnih duljina 37,805 km.

Grad Osijek skrbi o nerazvrstama cestama na području grada Osijeka. Pod nadležnošću Grada Osijeka nalazi se ukupno 579 cesta, a njihova ukupna duljina iznosi $242,695 \mathrm{~km}$. Na području grada Osijeka postoje, a ubrajaju se u nerazvrstane ceste, 44 ceste s tucaničkim zastorom, a njhova ukupna duljina iznosi 13,443 km. Održavanje nerazvrstanih cesta je komunalna djelatnost, sukladno Zakonu o cestama [3] i Zakonu o komunalnom gospodarstvu [10]. Za Grad Osijek poslove održavanja nerazvrstanih cesta obavlja Unikom d.o.o. Poslove projektiranja, izgradnje i održavanja semafora radi jedan koncesionar za sva tri pravna subjekta koji skrbe 0 cestama u gradu Osijeku, a to je Elektromodul d.o.o.

Uvidom u poslove održavanja cesta koji se provode u praksi uočava se različit odnos planskog i reaktivnog održavanja. Uočljiv je napor svih pravnih subjekata za održavanje pozitivnog trenda udjela planskog održavanja, u čemu su Hrvatske ceste - Ispostava Osijek otišle najdalje.

Predviđene aktivnosti i radove na sve tri razine - redovitog i izvanrednog održavanja i rekonstrukcije provode svi pravni subjekti sukladno Zakonu. Bazu podataka o cestama, uređajima za odvodnju i objektima u potpunosti vode Hrvatske ceste, dok Županijska uprava za ceste i Grad Osijek imaju relacijsku baza podataka u fazi formiranja. Bazu podataka o prometnim znakovima sva tri pravna subjekta uredno vode. Računalni model odlučivanja (HDM-4) imaju Hrvatske ceste, ali njegova uporaba nije u potpunosti zaživjela u praksi. Rekapitulacija radova održavanja koje pravni subjekti koji djeluju u Osijeku provode u praksi u kontekstu zakonskih i stručnih preporuka, prikazana je u tablici 3 .

\section{Tablica 3 - Analiza radova po pravnim subjektima u Osijeku u odnosu na zakonski okvir i stručne} preporuke

\begin{tabular}{|c|c|c|c|c|}
\hline & RADOVI & HC-OS & ŽUC & GRAD \\
\hline \multirow{21}{*}{  } & \multicolumn{4}{|l|}{ REDOVITO ODRŽAVANJE } \\
\hline & Radovi na kolniku & da & $\mathrm{da}$ & $\mathrm{da}$ \\
\hline & Radovi na bočnim dijelovima ceste & da & da & da \\
\hline & Radovi na uređajima za odvodnju & da & da & da \\
\hline & Radovi na održavanju vegetacije & da & da & da \\
\hline & Radovi na održavanju opreme ceste & da & da & da \\
\hline & Radovi na održavanju građevina & da & da & da \\
\hline & Održavanje u zimskim uvjetima & da & da & da \\
\hline & \multicolumn{4}{|l|}{ IZVANREDNO ODRŽAVANJE } \\
\hline & Izvanredno održavanje cesta & da & da & da \\
\hline & Izvanredno održavanje objekata & da & da & da \\
\hline & \multicolumn{4}{|l|}{ REKONSTRUKCIJA } \\
\hline & Projektna dokumentacija & da & da & da \\
\hline & Lokacijska dozvola & da & da & da \\
\hline & Građevinska dozvola & da & da & da \\
\hline & \multicolumn{4}{|l|}{ BAZA PODATAKA } \\
\hline & Baza podataka o cestama & da & u formiranju & u formiranju \\
\hline & Baza podataka o objektima & da & u formiranju & u formiranju \\
\hline & Baza podataka o znakovima & da & da & da \\
\hline & Baza podataka o uređajima za odvodnju & da & u formiranju & u formiranju \\
\hline & RAČUNALNI MODEL ODLUČIVANJA & da-nije u funkciji & ne & ne \\
\hline
\end{tabular}

\footnotetext{
${ }^{3}$ Karta razvrstanih cesta dobivena od Hrvatskih cesta Ispostave Osijek
} 


\section{Zaključak}

Intenzitet izgradnje nove cestovne prometne infrastrukture se smanjuje i dominatan značaj ima gospodarenje prometnom infrastrukturom. Zakonski okvir daje pravnim subjektima propisane postupke godišnjeg i višegodišnjeg planiranja redovitog i izvanrednog održavanja i rekonstrukcija. Zakon propisuje standard održavanja, razinu sigurnosti cesta i objekata, postupke nadzora i inspekcije cesta, te postupanje u izvanrednim okolnostima planiranog ili neplaniranog zatvaranja cesta. Zakonom propisani uvjet održavanja cesta je postojanje baze podataka o cestama. Stvaranje dobrog informacijskog sustava relevantnih podataka o stanju cesta i objekata daje jasan uvid u postojeće stanje cestovne infrastrukture, što je preduvjet za predviđanje budućeg stanja kolnika i objekata i analizu različitih strategija gospodarenja cestovnom inrastrukturom. Računalni modeli odlučivanja usmjereni su na upravljanje podatcima o cestama da bi na razini cjelokupne cestovne mreže bili dostupni, pravovremeni i relevatni.

U okviru ovog rada analizirano je funkcioniranje gospodarenja cestama u praksi. U gradu Osijeku djeluju tri pravna subjekta koji skrbe o cestovnoj mreži, a to su Hrvatske ceste - Ispostava Osijek, Uprava za ceste Osječko-baranjske županije i Grad Osijek. Sva tri pravna subjekta uredno obavljaju radove održavanja koji su propisani Zakonom. Baze podataka o cestama su uspostavljene (Hrvatske ceste) ili u fazi formiranja (županijska Uprava i Grad), ali primjena računalnih modela odlučivanja nije zaživjela u praksi.

Uspostavljanje sustava gospodarenja cestama iziskuje dodatna financijska ulaganja i napore koji se moraju usmjeriti u ustrojavanje baze podataka o cestama i računalnog modela upravljanja podatcima. Stvaranje tih preduvjeta će omogućiti formiranje i analizu različitih strategija i izbor optimalne strategije gospodarenja cestovnom infrastrukturom u lokalnim uvjetima. Uspostava sustava gospodarenja cestama je budućnost gospodarenja cestama i donijet će višestruke koristi donosiocima odluke, korisnicima i sustavu u cjelini, kao što pokazuju iskustva drugih zemalja u Europi i svijetu.

\section{Zahvale}

Autori se zahvaljuju Hrvatskim cestama - Ispostavi Osijek, Upravi za ceste Osječko-baranjske županije i Gradu Osijeku na uvidu u podatke o održavanju cestovne mreže na području grada Osijeka.

\section{Literatura}

[1] Zakon o sigurnosti prometa na cestama (NN 67/08, 74/11),

[2] Zakon o prostornom uređenju i gradniji (NN 76/07, 38/09, 55/11, 90/11)

[3] Zakon o cestama (NN 84/11)

[4] Pravilnik o zaštiti i održavanju javnih cesta (NN 25/98, 162/98)

[5] Pravilnik o osnovnim uvjetima kojima javne ceste izvan naselja i njihovi elementi moraju udovoljavati s gledišta sigurnosti prometa (NN 110/01)

[6] Pravilnik o minimalnim sigurnosnim zahtjevima za tunele (NN119/09)

[7] Pravilnik o uvjetima i postupku zatvaranja javnih cesta (NN119/07)

[8] Odluka o razvrstavanju javnih cesta u državne ceste, županijske ceste i lokalne ceste (NN 54/08, 122/00, $13 / 09,104 / 09$ i $17 / 10,44 / 12)$

[9] Odluka o razvrstavanju javnih cesta u autoceste (NN 77/07, 13/09 i 104/09)

[10] Zakon o komunalnom gospodarstvu (NN 26/03, 82/04,110/04, 178/04, 38/09, 79/09, 153/09, 49/11, 84/11 i 90/11)

[11] Keller M., 2009: Gospodarenje cestovnim kolnicima; Hrvatsko savjetovanje o održavanju cesta, Zbornik radova 2009, 41-53, Šibenik 
[12] Kuvačić B., Rukavina T., 2009: Sustav gospodarenja kolnicima na hrvatskim prometnicama - postavke i principi; Hrvatsko savjetovanje o održavanju cesta, Zbornik radova 2009, 33-41, Šibenik

[13] Hicks, R. G., Seeds, S. B., Peshkin, D. G., 2000: Selecting a preventive maintenance treatment for flexible pavements, Study for Foundation for Pavement Preservation, Washington, DC

[14] http://www.mdt511.comwww.mdt511.com/publications/docs/brochures/research/toolbox/FPP/SELECT.pdf 